\title{
Litterfall Production and Nutrient Deposition Through Leaf Fallen in three Tamaulipan Thornscrub Communities, North-eastern Mexico
}

ARTICLE · JANUARY 2014

DOI: 10.5958/0976-4038.2014.00551.X

DOWNLOADS

10

8 AUTHORS, INCLUDING:

Ratikant Maiti

R.K. MAITI RESEARCH FOUNDATION

38 PUBLICATIONS 151 CITATIONS

SEE PROFILE

Roque Gonzalo Ramírez-Lozano

Autonomous University of Nuevo León

114 PUBLICATIONS 474 CITATIONS

SEE PROFILE
VIEWS

34

H. González-Rodríguez

Autonomous University of Nuevo León

76 PUBLICATIONS 148 CITATIONS

SEE PROFILE

Marisela Pando-Moreno

Autonomous University of Nuevo León

58 PUBLICATIONS 86 CITATIONS

SEE PROFILE 


\title{
Litterfall Production and Nutrient Deposition Through Leaf Fallen in three Tamaulipan Thornscrub Communities, North-eastern Mexico
}

\author{
Juan Manuel Lopez Hernandez ${ }^{1}$, Ratikanta Maiti², Marco Vinicio Gomez Meza ${ }^{3}$, Humberto Gonzalez Rodriguez ${ }^{{ }^{*}}$, Israel \\ Cantu Silva ${ }^{1}$, Roque Gonzalo Ramirez Lozano ${ }^{4}$, Marisela Pando Moreno ${ }^{1}$, Andres Eduardo Estrada Castillon ${ }^{1}$
}

\author{
${ }^{1}$ Universidad Autonoma de Nuevo Leon, Facultad de Ciencias Forestales, Carr. Nac. No 85, km 145, Linares, Nuevo Leon, \\ 67700 Mexico \\ ${ }^{2}$ RKM Foundation, Fracc. Valle de las Flores, Avenida del Museo \# 1118, San Nicolas de los Garza, Nuevo Leon, Mexico, C.P. 66430 \\ ${ }^{3}$ Universidad Autonoma de Nuevo Leon, Facultad de Economia, Monterrey, Nuevo Leon, Mexico \\ ${ }^{4}$ Universidad Autonoma de Nuevo Leon, Facultad de Ciencias Biologicas, Monterrey, Nuevo Leon, Mexico
}

\section{Article History}

Manuscript No. 742a

Received in $5^{\text {th }}$ May, 2014

Received in revised form $15^{\text {th }}$ May, 2014

Accepted in final form 30 $0^{\text {th }}$ May, 2014

\section{Correspondence to}

*E-mail: humberto.gonzalezrd@uanl.edu.mx

\section{Keywords}

litterfall, leaves, Tamaulipan thornscrub, mineral deposition, north-eastern Mexico

\begin{abstract}
Litterfall and the contents of macro- and micro-nutrients derived from its decomposition contribute greatly to the growth and productivity of forest ecosystem. The present study was undertaken to know the variability during two years in the deposition of litterfall and deposition of nutrients through leaf fallen litterfall in three sites of the state of Nuevo Leon (Los Ramones, China and Linares), north-eastern Mexico, which encompasses the Tamaulipan thornscrub plant community. The quantities of litterfall production and its constituents varied between 2009 and 2010, being the year 2010 where higher litterfall and nutrients occured. Mean litterfall production during the two years showed the following trend: Los Ramones (364.8), China (522.7) and Linares $\left(583.1 \mathrm{~g} \mathrm{~m}^{-2}\right.$ year $\left.^{-1}\right)$. For leaf constituent, mean deposition ranged from 200.9 (Los Ramones) to $409.8 \mathrm{~g} \mathrm{~m}^{-2}$ year $^{-1}$ (Linares), twigs from 62.4 (Los Ramones) to 89.3 (Linares), reproductive structures from 62.5 (Linares) to 80.3 (Los Ramones) and the miscellaneous component, constituted by unidentified plant material, body and insect feces, ranged from 21.1 (Linares) to $32.7 \mathrm{~g} \mathrm{~m}^{-2}$ year-1 $^{-1}$ (China). During the two years, mean annual deposition of $\mathrm{Ca}+\mathrm{K}+\mathrm{Mg}+\mathrm{P}+\mathrm{N}$ for Los Ramones, China and Linares was 10.1, 21.5 and $24.8 \mathrm{~g} \mathrm{~m}^{-2}$ year $^{-1}$, respectively. Regardless of the research site, the order of macro and micro-nutrients deposition was as follows: $\mathrm{Ca}>\mathrm{N}>\mathrm{K}>\mathrm{Mg}>\mathrm{P}$ and $\mathrm{Fe}>\mathrm{Mn}>\mathrm{Zn}>\mathrm{Cu}$, respectively. There were spatial and temporal variations in litterfall deposition in terms of quantity, quality and potential nutrient returns. It is documented that the variability of litterfall and contents of nutrients derived from litterfall is influenced by the physioco-chemical characteristics of soils, diversity in vegetation and climatic conditions prevailing in different sites and years.
\end{abstract}

\section{Introduction}

A large number of plant species which are distributed in the northeast of Mexico are categorised in various groups, on the basis of their adaptation to ecological conditions and its forest use, which constitute the Tamaulipan thrornscrub vegetation. This semiarid shrubland covers about $200,000 \mathrm{~km}^{2}$ including southern Texas and north-eastern Mexico (Foroughbakhch, 1992; Foroughbakhch et al., 2005). The vegetation of this area consists of small trees and shrubs and it is composed by about 60 woody species, many of these are important for their utilization as forest products and for agroforestry purposes (forage source for domestic livestock and wildlife, fuelwood, timber for construction, medicine, reforestation practices in disturbed sites, wood, charcoal production, medicinal purposes, among other uses), which consitute the most common uses (Ludwig et al., 1975; Reid et al., 1990; Garrett, 2002).

The importance of litterfall in the return of nutrients and the accumulation of dry matter in the soil has been widely documented in different forest ecosystems (Jorgensen et al., 1975; Lugo et al., 1990; Dominguez, 2009; GonzalezRodriguez et al., 2013). Litterfall and its further decomposition are the main fundamental processes in nutrient cycling, which represent the main transfer of organic matter and nutrients to the soil surface (Isaac and Nair, 2006). Besides, throughfall 
and stemflow (Silva and Gonzalez, 2001) are the main source of natural fertilization to forest soil. More than half of the annual absorption of nutrients in the forests owns to the reincorporation of litterfal in the soil, and the subsequent recycle of these nutrients are the main source of nutrient availability (Del Valle-Arango, 2003).

The decomposition of litterfall is a crucial process for the maintenance of the fertility and productivity of the forest ecosystem (Prescott, 2005). Among these, the productivity of the plants depends greatly on the nutrient cycle (Gartner and Cardon, 2004). The seasonal fluctuations in the production of litterfall are regulated basically by the biological and environmental factors, athough land shape, edaphic conditions, plant species and cover, age and density of the forest are as well important to take into account (Hernandez et al., 1992). The main elements which control its degradation are the physicochemical environment, the characteristics of litterfall and the biotic elements involved during decomposition (Hattenschwiler et al., 2005). Hoorens et al. (2003) and Zhang et al. (2008) have shown that the quality of litterfall is one of the limiting factors which affects the rate of descomposition so that the majority of terrestrial ecosystems are integrated by a great variety of plant species, by which each contribute to the anual process, which implies that its composition exert a strong impact on this respect (Hattenschwiler et al., 2005). On the other hand, Tuomi et al. (2009) indicates that temperature and precipitation are key factors which affect degradation. Thus, decomposition of litterfall is a fundamental process that occurs in all types of ecosystems (Vasconcelos y Laurance, 2005).

In spite of the plant structure composition, ecological and biological studies well documented and undertaken in the Tamaulipan thronscrub in the north-eastern region of Mexico, and particularly in the state of Nuevo Leon, few studies have been addressed the deposition of plant nutrients through leaf fallen. Therefore, with an objective to understand and enrich these vital processes in this type of plant communities, the purpose of this research was to quantify during two years the production of litterfall and the potential deposition of macro(Ca, $\mathrm{K}, \mathrm{Mg}, \mathrm{N}$, and $\mathrm{P}$ ) and micro-minerals ( $\mathrm{Cu}, \mathrm{Fe}, \mathrm{Mn}$, and $\mathrm{Zn}$ ) through leaf fallen in three sites of north-eastern Mexico.

\section{Materials and Methods}

\subsection{Study area}

The study has been undertaken at three sites of the Tamualipan thornscrub, without any recent disturbance in the state of Nuevo Leon, north-eastern Mexico. Site 1 is located in Los Ramones county $\left(25^{\circ} 40 \mathrm{~N} ; 99^{\circ} 27 \mathrm{~W}, 200 \mathrm{~m}\right.$ asl). Site 2 is located in China county $\left(25^{\circ} 31 \mathrm{~N}, 99^{\circ} 16 \mathrm{~W}, 200 \mathrm{~m}\right.$ asl) and Site 3 is situated at the Experimental Research Station of the Faculty of Forest Sciences, Universidad Autonoma de Nuevo Leon $\left(24^{\circ}\right.$
$47 \mathrm{~N}, 99^{\circ} 32 \mathrm{~W}, 350 \mathrm{~m}$ asl), $8 \mathrm{~km}$ south of Linares county. The climate is subtropical and semiarid with warm summer. Monthly mean air temperature ranges from $14.7^{\circ} \mathrm{C}$ in January to $22.3^{\circ} \mathrm{C}$ in August, although daily high temperatures of $45^{\circ} \mathrm{C}$ are common during summer. Average total annual precipitation ranges from 600 to $805 \mathrm{~mm}$ with a bimodal distribution. The peak rainfall months are May, June and September (Gonzalez Rodriguez et al., 2004). The dominant soils are deep, darkgray, lime-gray, lime-clay Vertisols, with montmorillonite, which shrink and swell noticeably in response to changes in soil moisture content. Some physical and chemical properties of the soils at a depth of $0-20 \mathrm{~cm}$ at research sites are shown in Table 1 . In addition, registered monthly mean air temperatures $\left({ }^{\circ} \mathrm{C}\right)$ and monthly rainfall $(\mathrm{mm})$ are shown in Figure 1.

\subsection{Vegetation of the study area}

The main type of vegetation at research sites is known as Tamaulipan Thronscrub or Subtropical Thronscrub (SPPINEGI, 1986), which is charactirized by a formation of trees and shrubs, with dominant floristic elements between 4 and 6 $\mathrm{m}$ height, being perrenials or deciduous, thorny or non-thrny, with myrcophyllous simple or compunds leaves. The most abundant and representative species are Prosopis laevigata (Humb. \& Bonpl ex Willd.). M.C Johnst., Ebenopsis ebano (Berland.) Barneby \& J.W Grimes, Acacia amentacea DC., Castela erecta Turpin subsp texana (Torr. \& A.Gray) Cronquist, Celtis pallida Torr., Parkinsonia texana var. macra (IM Johnst.) Isely, Forestiera angustifolia Torr., Cordia boissieri A.DC., Leucophyllum frutescens (Berland.) IM Johnst., Guaiacum angustifolium Engelm., Cylindropuntia leptocaulis (DC.) F.M

Table 1: Some physical and chemical properties of soils (profile depth $0-20 \mathrm{~cm}$ ) at the studied sites, north-eastern Mexico

\begin{tabular}{lccc}
\hline \multirow{2}{*}{ Property } & \multicolumn{3}{c}{ Sites } \\
\cline { 2 - 4 } & Los Ramones & China & Linares \\
\hline Sand $\left(\mathrm{g} \mathrm{kg}^{-1}\right)$ & 425.0 & 230.0 & 94.0 \\
Silt $\left(\mathrm{g} \mathrm{kg}^{-1}\right)$ & 350.0 & 490.0 & 420.0 \\
Clay $\left(\mathrm{g} \mathrm{kg}^{-1}\right)$ & 225.0 & 280.0 & 486.0 \\
Bulk density $\left(\mathrm{Mg} \mathrm{m}^{-3}\right)$ & 1.2 & 1.3 & 0.9 \\
$\mathrm{pH}$ & 7.7 & 8.3 & 7.9 \\
$\mathrm{EC}\left(\mu \mathrm{S} \mathrm{cm}^{-1}\right)$ & 86.2 & 99.4 & 129.5 \\
Organic matter $(\%)$ & 1.8 & 5.8 & 8.6 \\
$\mathrm{Ca}\left(\mathrm{mg} \mathrm{kg}^{-1}\right)$ & 7366.1 & 8291.5 & 11704.6 \\
$\mathrm{Mg}\left(\mathrm{mg} \mathrm{kg}^{-1}\right)$ & 271.9 & 258.6 & 191.4 \\
$\mathrm{~K}\left(\mathrm{mg} \mathrm{kg}^{-1}\right)$ & 176.5 & 240.0 & 270.5 \\
$\mathrm{~N}\left(\mathrm{mg} \mathrm{kg}^{-1}\right)$ & 1694.4 & 1410.5 & 1938.3 \\
$\mathrm{Cu}\left(\mathrm{mg} \mathrm{kg}^{-1}\right)$ & 0.3 & 0.3 & 0.4 \\
$\mathrm{Mn}\left(\mathrm{mg} \mathrm{kg}^{-1}\right)$ & 6.5 & 6.1 & 5.5 \\
$\mathrm{Fe}\left(\mathrm{mg} \mathrm{kg}^{-1}\right)$ & 4.5 & 2.6 & 3.6 \\
$\mathrm{Zn}\left(\mathrm{mg} \mathrm{kg}^{-1}\right)$ & 0.3 & 0.2 & 0.2 \\
\hline
\end{tabular}


Knuth, Opuntia spp, Zanthoxylum fagara Sarg., Sideroxylon celastrinum (Kunth) T.D.Penn, Helietta parvifolia (A.Gray ex Hemsl) Benth. among others. The floristic structure composition at research sites has previously documented
(Dominguez et al., 2013) and it is shown in Table 2.

\subsection{Litterfall sampling and collection frequency}

At each site, ten litter canisters $\left(1.0 \mathrm{~m}^{2}\right)$, made with wooden

Table 2: General characteristics of plant species identified at the experimental plot of research sites, north-eastern Mexico. A, D, F and IV refer to abundance, dominace, frequency and importance value, respectively.

\begin{tabular}{|c|c|c|c|c|c|c|c|c|}
\hline \multirow[t]{2}{*}{ Sites } & \multirow[t]{2}{*}{ Phenology } & \multirow{2}{*}{$\begin{array}{l}\text { Number of } \\
\text { individuals }\end{array}$} & \multirow{2}{*}{$\begin{array}{c}\text { Height } \\
(\mathrm{m})\end{array}$} & \multirow{2}{*}{$\begin{array}{c}\text { Crown cover } \\
\left(\mathrm{m}^{2}\right)\end{array}$} & \multirow[t]{2}{*}{$\mathrm{A}(\%)$} & \multirow[t]{2}{*}{$\mathrm{D}(\%)$} & \multirow[t]{2}{*}{$\mathrm{F}(\%)$} & \multirow[t]{2}{*}{ IV $(\%)$} \\
\hline & & & & & & & & \\
\hline \multicolumn{9}{|l|}{ Los Ramones } \\
\hline Acacia amentacea & Deciduous & 50 & 2.4 & 153.4 & 8.8 & 7.2 & 3.2 & 19.3 \\
\hline Acacia farnesiana & Deciduous & 18 & 3.9 & 183.9 & 3.1 & 8.6 & 4.8 & 16.7 \\
\hline Castela erecta & Deciduous & 17 & 1.5 & 31.7 & 3.0 & 1.5 & 4.8 & 9.3 \\
\hline Celtis pallida & Deciduous & 52 & 3.0 & 195.8 & 9.1 & 9.2 & 6.4 & 24.9 \\
\hline Condalia hookeri & Deciduous & 14 & 2.9 & 63.7 & 2.4 & 3.0 & 4.8 & 10.3 \\
\hline Forestiera angustifolia & Deciduous & 22 & 2.0 & 61.3 & 3.8 & 2.9 & 6.4 & 13.2 \\
\hline Karwinskia humlboldtiana & Deciduous & 69 & 1.5 & 90.8 & 12.1 & 4.3 & 8.0 & 24.5 \\
\hline Parkinsonia texana & Deciduous & 14 & 3.5 & 113.5 & 2.4 & 5.3 & 2.4 & 10.2 \\
\hline Prosopis laevigata & Deciduous & 40 & 4.7 & 673.5 & 7.0 & 31.8 & 7.2 & 46.1 \\
\hline Syderoxylon lanuginosum & Deciduous & 41 & 3.0 & 166.7 & 7.2 & 7.8 & 5.6 & 20.7 \\
\hline Zanthoxylum fagara & Perennial & 45 & 2.5 & 135.5 & 7.9 & 6.4 & 4.8 & 19.2 \\
\hline \multicolumn{9}{|l|}{ China } \\
\hline Acacia amentacea & Deciduous & 45 & 1.8 & 104.8 & 6.4 & 9.7 & 6.8 & 23.0 \\
\hline Castela erecta & Deciduous & 40 & 1.7 & 82.3 & 5.7 & 7.6 & 6.8 & 20.2 \\
\hline Celtis pallida & Deciduous & 49 & 2.0 & 74.0 & 7.0 & 6.8 & 6.8 & 20.7 \\
\hline Ebenopsis ebano & Perennial & 19 & 2.7 & 98.0 & 2.7 & 9.0 & 4.8 & 16.6 \\
\hline Forestiera angustifolia & Deciduous & 52 & 1.7 & 89.6 & 7.4 & 8.3 & 1.3 & 17.1 \\
\hline Parkinsonia texana & Deciduous & 12 & 3.5 & 118.8 & 2.6 & 17.6 & 5.6 & 25.8 \\
\hline Guaiacum angustifolium & Perennial & 60 & 0.9 & 28.9 & 8.5 & 2.6 & 6.8 & 18.1 \\
\hline Prosopis laevigata & Deciduous & 16 & 3.2 & 194.3 & 2.2 & 18 & 6.2 & 26.5 \\
\hline Syderoxylon lanuginosum & Deciduous & 14 & 1.9 & 44.3 & 2.0 & 4.1 & 2.0 & 8.1 \\
\hline \multicolumn{9}{|l|}{ Linares } \\
\hline Acacia amentacea & Deciduous & 73 & 2.5 & 142.7 & 6.1 & 6.0 & 5.6 & 17.8 \\
\hline Acacia farnesiana & Deciduous & 4 & 6.3 & 86.1 & 0.3 & 3.6 & 1.6 & 5.7 \\
\hline Acacia schaffneri & Deciduous & 11 & 2.5 & 61.8 & 0.9 & 2.6 & 2.8 & 6.3 \\
\hline Castela erecta & Deciduous & 23 & 1.5 & 16.6 & 1.9 & 0.7 & 4.5 & 7.1 \\
\hline Celtis pallida & Deciduous & 28 & 3.4 & 149.4 & 2.3 & 6.3 & 5.0 & 13.8 \\
\hline Condalia hookeri & Perennial & 36 & 2.7 & 131.0 & 3.0 & 5.5 & 2.2 & 10.8 \\
\hline Cordia boissieri & Deciduous & 19 & 3.1 & 127.5 & 1.5 & 5.4 & 3.3 & 10.4 \\
\hline Dyospiros texana & Perennial & 34 & 2.7 & 123.3 & 2.8 & 5.2 & 0.5 & 8.6 \\
\hline Eysenhardtia texana & Deciduous & 33 & 3.5 & 183.2 & 2.7 & 7.8 & 5.6 & 16.2 \\
\hline Forestiera angustifolia & Deciduous & 19 & 1.8 & 37.4 & 1.5 & 1.5 & 4.5 & 7.7 \\
\hline Havardia pallens & Deciduous & 40 & 3.1 & 124.6 & 3.3 & 5.3 & 1.1 & 9.8 \\
\hline Lantana macropoda & Deciduous & 230 & 0.9 & 94.3 & 19.2 & 4.0 & 4.5 & 27.8 \\
\hline Leucophylium frutescens & Perennial & 32 & 1.5 & 41.4 & 2.6 & 1.7 & 3.9 & 8.4 \\
\hline Zanthoxylum fagara & Perennial & 38 & 2.2 & 67.0 & 3.1 & 2.8 & 5.0 & 11.1 \\
\hline
\end{tabular}


sides fitted with the nylon net bottom ( $1 \mathrm{~mm}$ mesh size), randomly scattered over an experimental plot of 2,500 $\mathrm{m}^{2}$ $\left(50 \times 50 \mathrm{~m}^{2}\right)$ were used for litterfall samplings. Each canister was placed approximately $0.30 \mathrm{~m}$ above the soil level to intercept litterfall. Litterfal sampling was conducted at 15-day intervals between January 2009 and December 2010. Monthly litterfall production was quantified by mixing the two samples taken every 15 days. Litterfall contents were manually sorted into the following categories: leaves, reproductive structures (flowers, fruits and seeds), twigs or branches ( $<2 \mathrm{~cm}$ in diameter), and miscellaneous residues (unidentified, fine plant tissue such as bark, pieces of insect bodies or feces). Corrections were not accounted for weight sample losses from litter which might have decomposed between sampling dates or amount of litter blown into or out of canisters by wind. Samples were oven dried to a constant weight at $65^{\circ} \mathrm{C}$ for $72 \mathrm{~h}$. Dry samples were ground in a Wiley mill (Thomas Scientific) to pass $1.0 \mathrm{~mm}$ mesh sieve and were kept in closed paper envelopes.

\subsection{Chemical analysis}

From each canister (replication), leaf litter samples obtained from each site and sampling date, $1.0 \mathrm{~g}$ dry weight was used for determining the contents of minerals $(\mathrm{Cu}, \mathrm{Fe}, \mathrm{Mn}, \mathrm{Zn}, \mathrm{Ca}$, $\mathrm{Mg}, \mathrm{K}$ and $\mathrm{P}$ ). Mineral content was estimated by incinerating samples in a muffle oven at $550^{\circ} \mathrm{C}$ during 5 hours. Ashes were digested in a solution containing $\mathrm{HCl}$ and $\mathrm{HNO}_{3}$, using the wet digestion technique (Cherney, 2000). Concentrations of $\mathrm{Ca}$ (oxide nitrous/acetylene flame), $\mathrm{Cu}, \mathrm{Fe}, \mathrm{Mn}, \mathrm{Zn}, \mathrm{K}$ and $\mathrm{Mg}$ (air/acetylene flame) were determined by atomic absorption spectrophotometry (Varian, model SpectrAA200), whereas $P$ was quantified spectrophotometrically using a Perkin-Elmer spectrophotometer (Model Lamda 1A) at 880 $\mathrm{nm}$ (AOAC, 1997). The Kjeldahl procedure was employed for total $\mathrm{N}$ analyses (AOAC, 1997). Nutrient deposition at each site was calculated by multiplying leaves litter production by each sampling date by nutrient concentration for the same sampling date and site, and adding them over the entire year. The accumulated values at each site were used as an estimate of the annual nutrient deposition.

\subsection{Statistical analysis}

Litterfall deposition data, per year and site, belonging to each litter constituent as well as, annual leaf nutrient deposition data were subjected to one-way analysis of variance with a factorial arrangement, being years (2009 and 2010) Factor A and Sites (Los Ramones, China and Linares) Factor B (Steel and Torrie, 1980). Normal distribution and homogeneity of variances for each litter constituent and nutrient deposition data were tested using the Kolmogorov-Smirnov, Shapiro-Wilk and Levene tests (Brown and Forsythe, 1974; Steel and Torrie, 1980). Where the interaction (years"sites) was significant $(p<0.05)$ the Tukey test $(p=0.05)$ was performed for mean comparison
(Steel and Torrie, 1980). All applied statistical methods were according to the SPSS ${ }^{\circledR}$ (Statistical Package for the Social Sciences) software package (standard released version 13.0 for Windows, SPSS Inc., Chicago, IL).

\section{Results and Discussion}

\subsection{Litterfall production}

Total litterfal production for Los Ramones, China and Linares during 2009 showed the following figures: 321, 431 and 462 $\mathrm{g} \mathrm{m}^{-2}$ year $^{-1}$, respectively, while for 2010 was 408, 613, and $703 \mathrm{~g} \mathrm{~m}^{-2}$ year $^{-1}$, respectively (Figure 2). The main litterfall constituent during the two years of study corresponded to leaf fallen, which represented in 2009 between 48\% (Los Ramones) and 65\% (Linares) and in 2010 between 60\% (Los Ramones) and $73 \%$ (Linares) of total litterfall production. The deposition of twigs for 2009 averaged $15 \%$ for the three sites, whereas during 2010 this component represented between $14 \%$ (Linares) and 18\% (Los Ramones) of total litterfall production. With respect to reproductive structures, during 2009 it represented between 12\% (Linares) and 30\% (Los Ramones), in contrast, during 2010 the deposition of this component ranged from 9\% (Linares) to 15\% (Los Ramones) of total litterfall. The deposition of miscellaneous during 2009 for the three sites represented $5 \%$ of total litterfall, whereas during 2010 it represented between 2\% (Linares) and 5\% (Los Ramones) of total litterfall deposition (Figure 2).

\subsection{Deposition of minerals}

The potential deposition of macro- and micro-minerals was significantly different among sites and years (Figure 2). The average deposition of $\mathrm{Ca}+\mathrm{K}+\mathrm{Mg}+\mathrm{P}+\mathrm{N}$ during the two studied years for Los Ramones, China and Linares was 10.1, 21.5 and $24.8 \mathrm{~g} \mathrm{~m}^{-2}$ year ${ }^{-1}$, respectively. The average deposition $\left(\mathrm{g} \mathrm{m}^{-2}\right.$ year $^{-1}$ ) of Ca during 2009 and 2010 for Los Ramones, China and Linares was 4.0, 6.4 and 11.3, respectively. Average K deposition was 1.7, 5.9 and 4.5, respectively; $\mathrm{Mg} 0.8,2.4$ and 1.5, respectively. Mean P deposition was $0.1,0.2$ and 0.2 , respectively. With respect to $\mathrm{N}$, mean deposition was 3.5 , 6.5 and 7.4, respectively (Figure 2). Regardless of site, the potential contribution of nutrients through leaf fallen showed the following trend: $\mathrm{Ca}>\mathrm{N}>\mathrm{K}>\mathrm{Mg}>\mathrm{P}$ (Figure 2). With respect to the potential deposition $\left(\mathrm{mg} \mathrm{m}^{-2}\right.$ year $\left.^{-1}\right)$ of $\mathrm{Cu}$ during 2009 , maximum (2.79) and minimum ( 0.83 ) values were observed in Linares and Los Ramones, respectively, whereas during 2010a similar trend, although of different magnitude, was registered; Linares and Los Ramones attained depositions of 4.87 and 0.95 $\mathrm{mg} \mathrm{m}^{-2}$ year $^{-1}$, respectively. Higher (11.8) and lower (5.5) Mn depositions during 2009 were recorded for Linares and Los Ramones, respectively. During 2010, Linares and Los Ramones achieved figures of 18.1 and 9.5, respectively. With respect to the depositions of Fe during 2009, Linares registered about 
21.7 while Los Ramones 14.7. During 2010, maximum (91.2) and minimum (53.0) values were observed in Linares and Los Ramones, respectively. It is clear the signinificant deposition of 2009 with respect to 2010 for these two sites. The maximum and minimum depsotion of $\mathrm{Zn}$ during 2009 was 5.2 and 3.3 for Linares and Los Ramones, respectively, whereas during 2010 was 9.0 and 5.9 for Linares and Los Ramones, respectively. Regardless of site, the potential deposition of micronutrients showed the following order: $\mathrm{Fe}>\mathrm{Mn}>\mathrm{Zn}>\mathrm{Cu}$ (Figure 2). Averaged total deposition of micronutrients through leaf fallen $(\mathrm{Cu}+\mathrm{Mn}+\mathrm{Fe}+\mathrm{Zn})$ for Los Ramones, China and Linares during
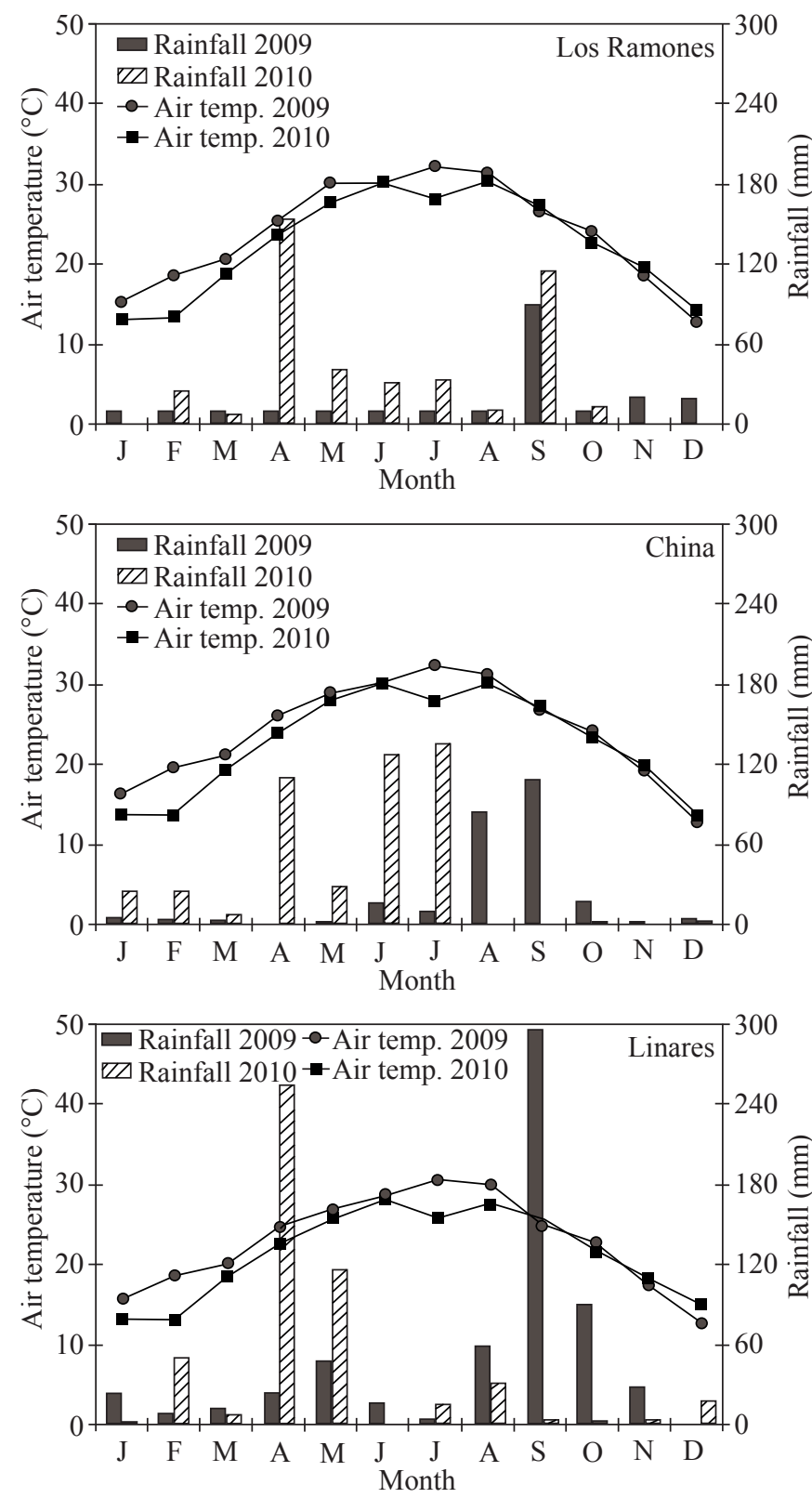

Figure 1: Monthly mean air temperature and monthly rainfall during 2009 and 2010 at Los Ramones, China and Linares, north-eastern Mexico
2009 was $24.3,28.4$ and $41.5 \mathrm{mg} \mathrm{m}^{-2}$ year $^{-1}$, respectively, while for 2010 was $69.2,77.4$ and 123.1, respectively.

The results of the present study have shown that the quantity
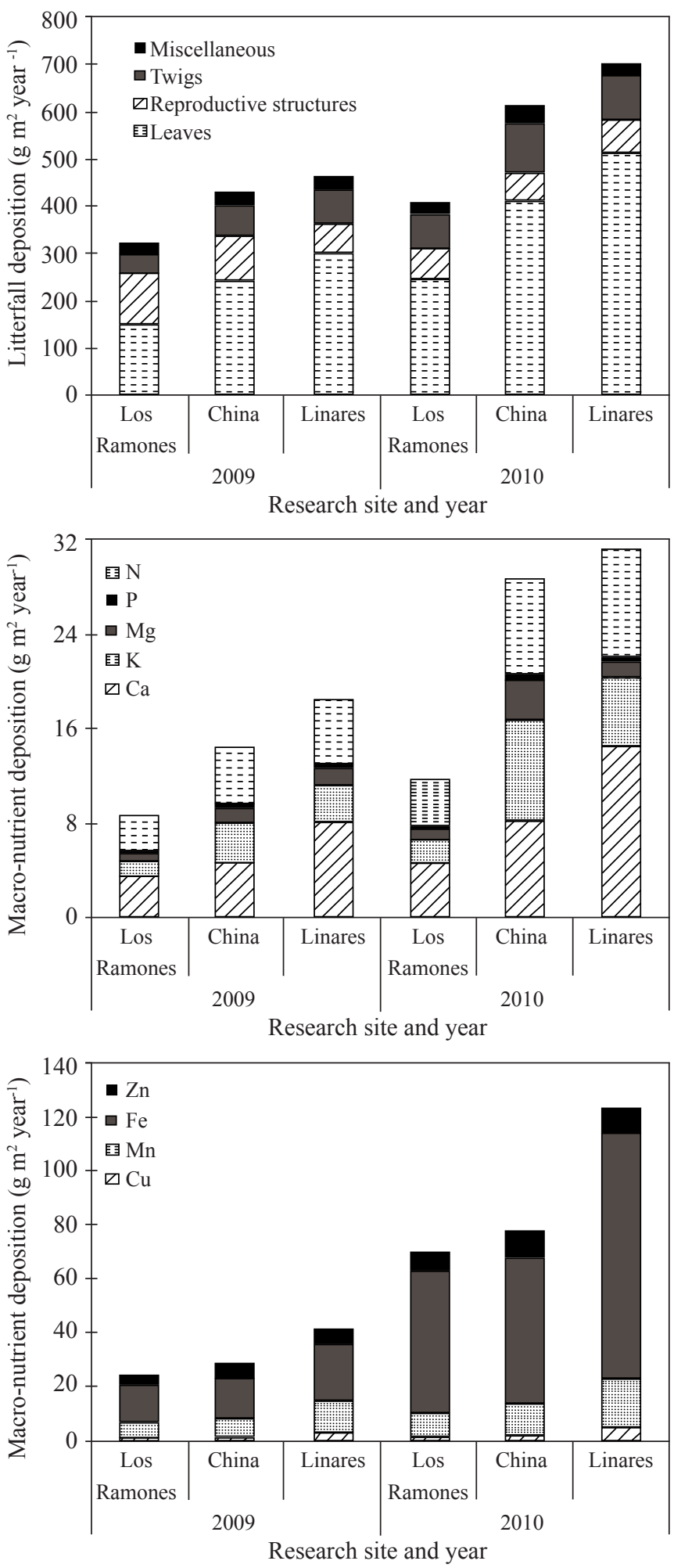

Figure 2: Litterfall, macro- and micro-nutrient deposition during 2009 and 2010 at research sites, north-eastern Mexico 
of litterfall deposition and its respective constituents differed between the two studied years; 2009 and 2010, being the last that registered the higher littefall production. This finding may be associated to the higher rainfall registered, particularly for sites Los Ramones and China. Although Linares accounted lower precipitation in the year 2010 with respect to 2009 , this research site accounted a greater litterfall production than China and Los Ramones sites. These observations could be realted to a greater plant cover and floristic diversity as well as to structure of the vegetation as has been previously documented (Dominguez et al., 2013). The results of the present study reveals also that there is a great variability in the deposition of litterfall and the contents of macronutrients derived from the decomposition of literfall among differnt sites exhibiting diversity in vegetation and weather conditions during the two years of study. In this context the importance of littefall in the contribution of macro- and micronutrients for the growth of forest ecosystem has been well documented (Jorgensen et al., 1975; Lugo et al., 1990; Isaac and Nair, 2006). The litterfal and its decomposition contribute to the main transfer of organic matter and nutrients to the soil surface (Isaac and Nair, 2006). Besides, nutrient fluxes occur via throughfall and stem flow (Silva and Gonzalez, 2001) to the forest soil. The decomposition of litterfal contribute to the maintenance of the fertility and productivity of the forest ecosystem (Prescott, 2005) and the reincorporation of litterfal in the soil, and the subsequent cycling of these nutrients are the main source of the available nutrients (Del Valle-Arango, 2003). It has been documented that the productivity of the plants depends greatly on the nutrient cycle (Gartner and Cardon, 2004) and also the seasonal fluctuations in the production of litterfal are regulated basically by the biological and climatic factors prevailing in the forest (Hernandez et al., 1992). In addition, the factors which control its degradation are the physicochemical environment, and litterfall and the composition of the community of decompossers (Hattenschwiler et al., 2005). The present study is supported by the results observed by Hoorens et al. (2003) and Zhang et al. (2008) whose reports about the quality of litterfall determines to some extent the grade of descomposition in the majority of terrestrial ecosystems which are realted to a great diversity of plant species which implies that its composition exerts a strong impact in this respect (Hattenschwiler, 2005).

The variation in litterfall in different sites is influenced by climatic parameters as has been reported by Tuomi et al. (2009) in which temperature and precipitation are the main factors that affect litterfall degradation.

\section{Conclusions}

During the two year period, the main litterfall component was constitued by leaf fallen comprising from 55 (Los Ramones) to $70 \%$ (Linares) of total litterfall. It was followed by reproductive structures which contributed from 11 (Linares) to 22\% (Los Ramones). At the three research sites, twigs avegaged about $16 \%$ of total litterfall. The miscelleaneous component ranged from 4 (Linares) to $6 \%$ (China). The dynamics of litterfall deposition is the result of phenological events of different species as well as it is realted to floristic composition at each research site and also to the environmental factors such us precipitation. The results of this investigation indicate that the deposition of macro-nutrients ( $\mathrm{Ca}, \mathrm{K}, \mathrm{Mg}, \mathrm{P}$, and $\mathrm{N}$ ) through leaf fallen was greater during the year 2010 with respect to 2009 , being Linares the site which showed the higher deposition of nutrients. During the two year study, the averaged deposit of $\mathrm{Ca}+\mathrm{K}+\mathrm{Mg}+\mathrm{P}+\mathrm{N}$ for sites Los Ramones, China and Linares was $10.1,21.5$ and $24.8 \mathrm{~g} \mathrm{~m}^{-2}$ year ${ }^{-1}$, respectively. Regardless of the site, the order of macro-nutrient deposition was as follows: $\mathrm{Ca}>\mathrm{N}>\mathrm{K}>\mathrm{Mg}>\mathrm{P}$. The deposition of micro-nutrients $(\mathrm{Cu}, \mathrm{Fe}, \mathrm{Mn}$ and $\mathrm{Zn}$ ) through leaf fallen was higher during 2010 that 2009. During the two year study, averaged deposition of $\mathrm{Cu}+\mathrm{Fe}+\mathrm{Mn}+\mathrm{Zn}$ for Los Ramones, China and Linares sites was $46.7,52.9$ and $82.3 \mathrm{mg} \mathrm{m}^{-2}$ year $^{-1}$, respectively. Regardless of research site, the order of micro-nutrients deposition was as follows: $\mathrm{Fe}>\mathrm{Mn}>\mathrm{Zn}>\mathrm{Cu}$. Deposition of $\mathrm{Fe}$ was significantly higher during 2010 with respect to 2009. This finding suggests a new line of research to elucidate main factors associated to its deposition and its relationships to climatic factors, soil physical and chemical properties, and root absorption and translocation mechanisms.

\section{Acknowledgements}

The authors wish to thank to the Consejo Nacional de Ciencia and Tecnologia (CONACYT) for the Doctoral Scholarship given to the first author. Valuable technical assistance provided by Manuel Hernandez, Perla Cecilia, Christian Marroquin and Elsa Gonzalez is highly recognized during their field and laboratory activities. The authors appreciate and wish to thank the land owners of Zaragoza and El Abuelo ranches for providing the facilities to conduct this investigation. This research was funded in part by Universidad Autonoma de Nuevo Leon (grant PAICYT CT289-10).

\section{References}

Association of Official Analytical Chemists (AOAC). 1990. Official methods of analysis, $15^{\text {th }}$ edn. Washington, DC. Association of Official Analytical Chemists, 482.

Brown, M.B., Forsythe, A.B., 1974. Robust tests for the equality of variances. Journal of the American Statistical Association 69, 364-367.

Cherney, D.J.R., 2000. Characterization of forages by chemical 
analysis. In: Givens, D.I., E Owen, RFE Axford, HM Omed eds. Forage evaluation in ruminant nutrition. $\mathrm{CAB}$ International, Wallingford, p. 281-300.

Del Valle-Arango, J.I., 2003. Cantidad, calidad y nutrientes reciclados por la hojarasca fina de bosques pantanosos del Pacifico Sur Colombiano. Interciencia 28, 443-449.

Dominguez, G.T.G., 2009. Deposicion de hojarasca y retorno potencial de nutrimentos en diferentes comunidades de vegetacion". Tesis de maestria en ciencias forestales. Facultad de Ciencias Forestales, Universidad Autonoma de Nuevo Leon. Linares, Nuevo Leon, Mexico. 132 pp.

Dominguez, G.T.G., Gonzalez, R.H., Ramirez, R.G., Estrada, C.A.E., Canti, S.I., Gomez, M.V., Alanis, F.G., 2013. Diversidad estructural del matorral espinoso tamaulipeco durante las epocas seca and himeda. Revista Mexicana de Ciencias Forestales 4(17), 106-123.

Foroughbakhch, R., 1992. Establishment and growth potential of fuelwood species in north-eastern Mexico. Agroforestry Systems 19, 95-108.

Foroughbakhch, R., Reyes, R.G., Alvarado, V.M., Hernandez, A., Pinero, J.L., Rocha, A., 2005. Use of quantitative methods to determine leaf biomass on 15 woody shrub species in north-eastern Mexico. Forest Ecology and Management 216, 359-366.

Garrett, H., 2002. Texas tree. A lone star book. Traylor Trade Publishing Lanham, Maryland, $253 \mathrm{pp}$.

Gartner, T.B., Cardon, Z.G., 2004. Decomposition dynamics in mixed-species leaf litter. Oikos 104, 230-246.

Gonzalez, R.H., Canti, I., Gomez, M.V., Ramirez, R.G., 2004. Plant water relations of thornscrub shrub species, north-eastern Mexico. Journal of Arid Environments 58, 483-503.

Gonzalez-Rodriguez, H., Ramirez-Lozano, R.G., Canti-Silva, I., Gomez-Meza, M.V., Cotera-Correa, M., CarrilloParra, A., Marroquin-Castillo, J.J., 2013. Produccion de hojarasca y retorno de nutrientes via foliar en un matorral desertico microfilo en el noreste de Mexico. Revista Chapingo Serie Ciencias Forestales and del Ambiente XIX(2), 249-262.

Hattenschwiler, S., 2005. Effects of Tree Species Diversity on Litter Quality and Decomposition. In: Scherer-Lorenzen, M., Ch. Korner and E. D. Schulze (eds.). Forest Diversity and Function: Temperate and Boreal Systems. Ecological Studies 176, 149-164.

Hattenschwiler, S., Tiunov, A.V., Scheu, S., 2005. Biodiversity and litter decomposition in terrestrial ecosystems. Annual Review Ecology Evolution and Systematics 36, 191-218.
Hernandez, I.M., Santa Regina, I., Gallardo, J.F., 1992. Dinamica de la descomposicion de la hojarasca forestal en bosques de la Cuenca del Duero (Provincia de Zamora): Modelizacion de la perdida de peso. Arid Soil Research and Rehabilitation 6, 339-355.

Hoorens, B., Aerts, R., Stroetenga, M., 2003. Does initial litter chemistry explain litter mixture effects on decomposition? Oecologia 137, 578-586.

Isaac, S.R., Nair, M.A., 2006. Litter dynamics of six multipurpose trees in a homegarden in Southern Kerala, India. Journal of Agroforestry System 67, 203-213.

Jorgensen, J.R., Well, C.G., Metz, L.J., 1975. The nutrient cycle: key to continuous forest production. Journal of Forestry 73, 400-403.

Ludwig, J.A., Reynold, J.F., Whitson, P.D., 1975. Size biomass relationships of several Chihuahuan desert shrubs. American Midland Naturalist 94, 451-461.

Lugo, A.E., Cuevas, E., Sanchez, M.J., 1990. Nutrients and mass in litter and top soil of ten tropical tree plantations. Plant and Soil 125, 263-280.

Prescott, C.E., 2005. Do rates of litter decomposition tell us anything we really need to know? Forest Ecology and Management 220, 66-74.

Reid, N., Marroquin, J., Beyer-Munzel, P., 1990. Utilization of shrubs and trees for browse, fuelwood and timber in the Tamaulipan thornscrub, north-eastern Mexico. Forest Ecology and Management 36, 61-79.

SPP-INEGI. 1986. Sintesis geografica del Estado de Nuevo Leon. Secretaria de Programacion y Presupuesto. Instituto Nacional de Geografia e Informatica, Mexico.

Silva, I.C., Gonzalez, R.H., 2001. Interception loss, throughfall and stem flow chemistry in pine and oak forests in northeastern Mexico. Tree Physiology 21, 1009-1013.

Steel, R.G.D., Torrie, J.H., 1980. Principles and procedures of statistics. A biometrical approach, $2^{\text {nd }}$ edn. New York, NY. McGraw-Hill Book Company. 633 p.

Tuomi, M., Thum, T., Jarvinen, H., Fronzek, S., Berg, B., Harmon, M., Trofymow, J.A., Sevanto, S., Liski, J., 2009. Leaf litter decomposition-Estimates of global variability based on Yasso07 model. Ecological Modelling 220, 3362-3371.

Vasconcelos, H.L., Laurance, W.F., 2005. Influence of habitat, litter type, and soil invertebrates on leaf-litter decomposition in a fragmented Amazonian landscape. Oecologia 144, 456-462.

Zhang, D., Hui, D., Luo, Y., Zhou, G., 2008. Rates of litter decomposition in terrestrial ecosystems: global patterns and controlling factors. Journal of Plant Ecology 1, 85-93. 